\title{
DISKRIMINASI DALAM NOVEL ANAK SEMUA BANGSA KARYA PRAMOEDYA ANANTA TOER DAN IMPLIKASINYA DALAM PEMBELAJARAN BAHASA INDONESIA DI SMA
}

\author{
Gita Tri Lestari \\ Pendidikan Bahasa dan Sastra Indonesia, Fakultas Keguruan dan Ilmu Pendidikan, \\ Universitas Pancasakti Tegal, Email: gitatrilestari3@gmail.com

\section{Sri Mulyati} \\ Pendidikan Bahasa dan Sastra Indonesia, Fakultas Keguruan dan Ilmu Pendidikan, \\ Universitas Pancasakti Tegal, Email: srimulyati03@gmail.com

\section{Vita Ika Sari} \\ Pendidikan Bahasa dan Sastra Indonesia, Fakultas Keguruan dan Ilmu Pendidikan, \\ Universitas Pancasakti Tegal, Email: vitaidea859799@gmail.com
}

\begin{abstract}
Abstrak
Novel Anak Semua Bangsa karya Pramoedya Ananta Toer. Novel ini berlatar belakang kolonial Hindia Belanda. Pada kenyataannya, dalam kehidupan manusia sering terjadi banyak kasus diskriminasi yang dilakukan oleh para penguasa dan dialami oleh kaum tertindas. Diskriminasi pada novel Anak Semua Bangsa karya Pramoedya Ananta Toer tercermin dalam gambaran betapa menderita dan terpuruknya bangsa pribumi Jawa akibat kekejaman yang dilakukan penjajah Belanda. Penelitian ini bertujuan untuk mendeskripsikan bentuk diskriminasi dalam novel Anak Semua Bangsa karya Pramoedya Ananta Toer dan implikasinya dalam pembelajaran bahasa Indonesia di SMA. Pendekatan kualitatif digunakan pada penelitian ini, dengan jenis penelitian deskriptif.. Penelitian ini menggunakan sumber data dari novel Anak Semua Bangsa karya Pramoedya Ananta Toer dengan wujud datanya yaitu penggalan wacana dan kalimat yang mengandung diskriminasi. Hasil penelitian ditemukan 48 data yang mengandung empat bentuk diskriminasi, yaitu diskriminasi suku/etnis, ras dan agama/keyakinan sebanyak 26 data (54,17\%), diskriminasi berdasarkan jenis kelamin dan gender sebanyak 8 data (16,67\%), diskriminasi terhadap penderita penyakit menular sebanyak 2 data $(4,16 \%)$, dan diskriminasi karena kasta sosial sebanyak 12 data $(25,00 \%)$.
\end{abstract}

Kata kunci: diskriminasi, novel dan implikasi.

\section{Abstract}

Novel Children of All Nations by Pramoedya Ananta Toer. This novel has a colonial background in the Dutch East Indies. In fact, in human life cases of discrimination often occur by the authorities and experienced by the oppressed. Discrimination in Pramoedya Ananta Toer's novel Anak Semua Bangsa is reflected in the description of the suffering and decline of the Javanese indigenous people due to atrocities committed by the Dutch colonialists. This study aims to describe the forms of discrimination in the novel Children of All Nations by Pramoedya Ananta Toer and their implications in learning Indonesian in high school. This research uses a qualitative approach, a type of descriptive research. The source of data in this study is the novel Children of All Nations by Pramoedya Ananta Toer with the form of data that is discourse fragments and sentences that contain discrimination. The results found 48 data containing four forms of discrimination, namely ethnic / ethnic, racial and religious / belief discrimination as much as 26 data $(54.17 \%)$, discrimination based on gender and gender as much as 8 data (16.67\%), discrimination against infectious disease sufferers as much as 2 data (4.16\%), and discrimination because of social caste as many as 12 data $(25.00 \%)$.

Keywords: discrimination, novels and implications. 


\section{PENDAHULUAN}

Karya sastra memiliki banyak genre, satu jenis genre karya sastra selain puisi, cerpen, dan drama adalah novel. Cerita fiksi yang ditulis dalam bentuk naratif yaitu novel. Novel biasanya menceritakan kehidupan manusia dalam berinteraksi pada lingkungan dan sesamanya, dengan menitik beratkan bagian tertentu pada unsurunsurnya. Unsur ekstrinsik dalam novel merupakan suatu unsur yang secara langsung membangun sebuah cerita. Keterpaduan unsur ekstrinsik ini akan menjadikan sebuah novel yang sangat bagus. Bagi kehidupan manusia karya sastra yang bermutu pasti terkandung sebuah nilai-nilai yang berguna.

Pengkajian sebuah karya sastra berarti penelaahan, penyelidikan karya sastra tersebut. Penelitian ini akan memfokuskan pada penelaahan unsur ekstrinsik, yaitu pada novel Anak Semua Bangsa karya Pramoedya Ananta Toer. Novel ini dengan latar belakang kolonial Hindia Belanda, dan Minke sebagai tokoh utama adalah seorang pelajar pribumi yang bersekolah di HBS.

Minke pandai dalam menulis, tulisannya telah diterbitkan oleh koran-koran Belanda.

Melalui tulisannya minke hanyalah seorang pribumi yang hidup dilingkungan Eropa, dan digambarkan sebagai seorang yang pemberani membrontak dalam melawan penindasan serta ketidakadilan pada negerinya. Minke bertemu dengan seorang perempuan cantik yang berketurunan Indonesia Belanda yaitu Annelise dan pada akhirnya menjadi istrinya. Annelise merupakan anak seorang nyai yang dipanggil sebagai Nyai Ontosoroh.

Pada kenyataannya, dalam kehidupan manusia sering terjadinya kasus diskriminasi yang banyak dilakukan penguasa dan dialami kaum yang tertindas. Munculnya istilah diskriminasi terhadap kaum yang lemah tidak terlepas dari hadirnya gerakan ketidakadilan. Diskriminasi novel Anak Semua Bangsa karya Pramoedya Ananta Toer tercermin dalam gambaran betapa menderita dan terpuruknya bangsa pribumi Jawa akibat kekejaman yang dilakukan penjajah Belanda. Adanya penelitian ini diharapkan para pembaca novel dapat memahami unsur ekstrinsik yang terkandung di dalamnya sehingga dapat memahami nilai-nilai kehidupan khususnya di kalangan pelajar.

Melihat fenomena dan pentingnya pembelajaran karya sastra, pengkajian novel dalam pembelajaran bahasa Indonesia dapat dijadikan sebagai ajang belajar tentang pembelajaran sastra di sekolah. Maka penulis tertarik melakukan penelitian dan menetapkan judul "Diskriminasi dalam Novel Anak Semua Bangsa Karya Pramoedya Ananta Toer dan Implikasinya dalam Pembelajaran Bahasa Indonesia di SMA". Tujuan penelitian merupakan apa yang akan dicapai dari penelitian ini, yaitu: mendeskripsi bentuk diskriminasi dalam novel Anak Semua Bangsa karya Pramoedya Ananta Toer dan mendeskripsi implikasi 
hasil penelitian dalam pembelajaran bahasa Indonesia di SMA.

\section{METODE}

Penelitian ini termasuk penelitian kualitatif. Prosedur penelitian jenis ini memperoleh data deskripsi berupa kata-kata tertulis (Santika, 2019). Penelitian ini menggunakan pendekatan kualitatif, berkaitan pada data penelitian bukan berupa angka-angka, namun berupa kualitas bentukbentuk verbal yang berujud tuturan yang tidak dikualifikasikan sehingga pada penelitian ini tidak digunakan secara statistis.

Penelitian ini menggunakan satu sumber data novel Anak Semua Bangsa karya Pramoedya Ananta Toer, tebal buku yaitu 539 halaman. Novel tersebut merupakan sebuah cetakan ketiga yang diterbitkan oleh Penerbit Lentera Dipantara pada tahun 2006. Data penelitian ini yaitu semua bahan yang berhubungan dengan diskriminasi dalam novel Anak Sетиа Bangsa karya Pramoedya Ananta Toer. Data termasuk bagian terpenting pada penelitian yang merupakan bagian dari keseluruhan proses pengumpulan data. Data mentah yang dikumpulkan penulis mengandung diskriminasi, adapun wujud data pada penelitian ini yaitu penggalan wacana dan kalimat-kalimat yang terdapat dalam dalam novel Anak Semua Bangsa karya Pramoedya Ananta Toer.
Teknik yang digunakan untuk pengumpulan data menggunakan teknik pengumpulan data sekunder. Teknik yang disebut teknik studi pustaka, yaitu data yang dikumpulkan berupa sumber data tertulis (Santika, 2019). Teknik tersebut merupakan teknik dasar pada pengumpulan data dalam penelitian ini, kemudian untuk teknik lanjutannya yaitu teknik baca dengan teknik catat. Cara membaca dengan cermat, teliti serta terarah pada sumber data merupakan teknik baca yang dilakukan pada penelitian ini. Hasil pembacaan kemudian dicatat sebagai data yang akan dianalisis peneliti. Teknik analisis data yang digunakan pada penelitian ini yaitu teknik analisis data deskriptif kualitatif.

3. HASIL DAN PEMBAHASAN

a. Bentuk Diskriminasi dalam Novel Anak Semua Bangsa Karya Pramoedya Ananta Toer

Bentuk diskriminasi penelitian ini didasarkan pada teori yang dikemukakan Fulthoni, et.al (2009:9) memaparkan bentuk atau jenis yang kerap terjadi, yaitu: 1) diskriminasi suku bangsa, etnis, ras dan agama/keyakinan, 2) diskriminasi jenis kelamin dan gender, 3) diskriminasi pada penyandang cacat, 4) diskriminasi terjadi pada penderita penyakit menular, dan 5) diskriminasi karena kasta sosial. 
Tabel 1. Diskriminasi dalam Novel Anak Semua Bangsa karya Pramoedya Ananta Toer

\begin{tabular}{|c|l|c|c|}
\hline No & \multicolumn{1}{|c|}{ Bentuk Diskriminasi } & Jml Data & Persentase \\
\hline 1. & $\begin{array}{l}\text { Diskriminasi suku bangsa, etnis, ras dan agama/ } \\
\text { keyakinan }\end{array}$ & 26 & $54,17 \%$ \\
\hline 2. & Diskriminasi berdasarkan jenis kelamin dan gender & 8 & $16,67 \%$ \\
\hline 3. & Diskriminasi terhadap penderita penyakit menular & 2 & $4,16 \%$ \\
\hline 4. & Diskriminasi karena kasta sosial & 12 & $25,00 \%$ \\
\hline \multicolumn{2}{|c|}{ Jumlah } & 48 & $100 \%$ \\
\hline
\end{tabular}

Hasil penelitian tentang kajian bagi guru bahasa Indonesia untuk bahan
diskriminasi dalam novel Anak Semиa Bangsa karya Pramoedya Ananta Toer ditemukan 48 data yang mengandung empat bentuk diskriminasi, yaitu diskriminasi suku/etnis, ras dan agama/keyakinan sebanyak 26 data $(54,17 \%)$, diskriminasi berdasarkan jenis kelamin dan gender sebanyak 8 data $(16,67 \%)$, diskriminasi terhadap penderita penyakit menular sebanyak 2 data $(4,16 \%)$, dan diskriminasi karena kasta sosial sebanyak 12 data $(25,00 \%)$. Sedangkan untuk diskriminasi terhadap penyandang cacat tidak ditemukan dalam novel tersebut. Diskriminasi dalam novel tersebut paling banyak menonjol yaitu diskriminasi suku/etnis, ras dan agama/keyakinan. Berikut pembahasan diskriminasi dalam novel Anak Semua Bangsa karya Pramoedya Ananta Toer.

b. Implikasi Diskriminasi dalam Novel

Anak Semua Bangsa Karya Pramoedya Ananta Toer dalam

Pembelajaran Bahasa Indonesia di SMA

Hasil penelitian ini mempunyai implikasi positif terhadap pembelajaran bahasa di SMA dan dapat bermanfaatkan kajian dalam pembelajaran materi pokok "Nilai-nilai dalam buku pengayaan (nonfiksi) dan buku drama (fiksi)" pada peserta didik SMA semester XII/Genap, dengan Kompetensi Dasar (KD) 3.14 Mengidentifikasi nilai-nilai yang terdapat pada sebuah buku pengayaan (nonfiksi) dan satu buku drama (fiksi) dan 4.14 Menulis refleksi mengenai nilai-nilai yang terdapat dalam sebuah buku pengayaan (nonfiksi) dan satu buku drama (fiksi).

Pembelajaran diskriminasi pada novel dapat diimplikasikan pada pembelajaran menentukan nilai-nilai yang ada dalam sebuah buku pengayaan (nonfiksi) dan satu buku drama (fiksi) dengan tujuan peserta didik dapat:

a. Mengidentifikasi nilai-nilai yang terdapat dalam novel.

b. Menyusun sebuah laporan refleksi nilainilai kehidupan nyata dari buku fiksi/nonfiksi yang dibaca.

c. Mempresentasikan laporan novel yang ditulisnya.

Implikasi diskriminasi pada novel Semua Anak Bangsa karya Pramodya Ananta Toer dapat diterapkan pada KD 3.14 
dan 4.14. sehingga dalam mengidentifikasi nilai-nilai yang terdapat dalam sebuah buku dapat digunakan novel. Pengajaran bahasa Indonesia selama ini di sekolah lebih mementingkan tata bahasa, struktur kalimat serta teori-teori ataupun lainnya. Hal tersebut justru membosankan dan kurang menarik minat peserta didik. Kreatifitas seorang guru sangat diperlukan pada suasana pengajaran untuk siswa lebih tertarik pada pembelajaran bahasa sastra.

Bagi pelajar SMP dan SMA, minat baca karya sastra, yang termasuk novel merupakan sebuah fenomena baru dan sesuatu hal yang baik. Di tengah-tengah gencarnya tayangan sinetron tidak mendidik di media televisi, dengan meluangkan waktu untuk membaca sebuah novel akan pemperkuat rasa estetika yang dimiliki dengan minat baca siswa. Membaca novel adalah tindakan awal untuk menarik minat siswa mempelajari hasil-hasil karya sastra di sekolah

\section{PENUTUP}

Novel Anak Semua Bangsa karya Pramoedya Ananta Toer menceritakan pada masa itu kata "keberadaban" lebih banyak membahas mengenai bagaimana orang Eropa bertingkah baik dan beradab sedangkan pribumi dinilai tidak memiliki tingkat keberadaban seperti Eropa. Sebagai manusia, kita tidak boleh merasa rendah akan jati diri kita, siapapun kita dan dari etnis manapun. Semua manusia sebenarnya sama, yang membedakan adalah bagaimana kita bersikap terhadap sesama manusia.

Novel Anak Semua Bangsa karya Pramoedya Ananta Toer menceritakan keadaan rakyat Jawa di bawah kepemerintahan Belanda yang licik serta haus kekuasaan. Sudut pandang Diskriminasi, penulis sangat mendewakan bangsa Eropa, dengan ini kita dapat melihat kembali sejarah pada bangsa Indonesia, serta bercermin pada diri sendiri. Kita dibawa menelusuri jalan pikiran Minke yang begitu terombang-ambing dalam keyakinannya, sampai pada akhirnya tersadar bahwa ia harus berani dan memperhatikan bangsanya. Melewati banyak berbagai peristiwa, bertemu dengan berbagai macam orang dengan segala opininya masing-masing, mengubah total cara berpikir Minke. Bangsa Eropa dulu sangat diagung-agungkannya, Eropa bahkan tak pernah salah menurutnya, Eropa maju dengan ilmu pengetahuannya, sedangkan pribumi hanya disuruh-suruh. Dengan bantuan para sahabatnya, pada kenyataan ia melihat kebusukan-kebusukan Eropa yang sesungguhnya. Banyak belajar, sikap seseorang tidak ditentukan oleh kebangsaannya. Ia tersadar, sebagai pribumi yang terpelajar serta banyak Bahasa yang dikuasainya, ia kini salah satu dari segelintir yang bisa menggerakkan dan memajukan bangsanya sendiri.

Diskriminasi dalam novel Anak Semua Bangsa karya Pramoedya Ananta Toer ditemukan 48 data, adapun bentuk diskriminasi tersebut antara lain diskriminasi 
suku/etnis, ras dan agama/keyakinan sebanyak 26 data $(54,17 \%)$, diskriminasi berdasarkan jenis kelamin dan gender sebanyak 8 data $(16,67 \%)$, diskriminasi terhadap penderita penyakit menular sebanyak 2 data $(4,16 \%)$, dan diskriminasi karena kasta sosial sebanyak 12 data $(25,00 \%)$. Sedangkan untuk diskriminasi terhadap penyandang cacat tidak ditemukan dalam novel tersebut. Diskriminasi dalam novel tersebut paling banyak yaitu diskriminasi suku/etnis, ras dan agama/keyakinan.

Hasil penelitian mempunyai implikasi positif terhadap pembelajaran bahasa di SMA dan dapat dimanfaatkan oleh guru bahasa Indonesia sebagai bahan kajian dalam pembelajaran materi pokok "Nilainilai dalam buku pengayaan (nonfiksi) dan buku drama (fiksi)" pada peserta didik SMA semester XII/Genap, dengan Kompetensi Dasar (KD) 3.14 Menerapkan nilai-nilai yang terdapat dalam sebuah buku pengayaan (nonfiksi) dan satu buku drama (fiksi) dan 4.14 Menulis sebuah refleksi mengenai nilainilai yang terkandung dalam sebuah buku pengayaan (nonfiksi) dan satu buku drama (fiksi).

\section{Ucapan Terima Kasih}

Ucapan terima kasih kusampaikan kepada semua yang telah membantu sehingga karya ilmiah ini bisa terselesaikan. Pada kesempatan ini ucapan terima kasih kami sampaikan kepada" a. Orang tuaku Bapak Sugianto dan Ibuku Watikah yang tercinta, tak pernah merasa lelah membesarkanku dengan penuh kasih sayang, serta memberi banyak dukungan, perjuangan, motivasi dan pengorbanan dalam hidupku.

b. Kedua kakakku tersayang dan serta kakak iparku (Andri Setiawan dan Laela Fitriyani) dan (Lina Indriani dan M. Saefudin) yang selalu memberikan dukungan, keponakan-keponakanku (Rizka, Arfan, Hasan, Husain) yang terus mengisi hariku dengan canda tawa dan kasih sayangnya.

c. TerTOP (Muhammad Farkhan) yang menemani sejak SMP hingga saat ini terus menyemangati, memberikan motivasi dan dukungan penuh, doa serta rasa sayang cintanya yang indah untukku. Thank's you for your love. Semangat juga untuk mu menyelesaikan kuliah.

d. Sahabat seperjuanganku Ayuningtyas Srikandini, Siti Nurjanah, Agustya Dyah $\mathrm{N}$, telah memberi semangat, dukungan serta canda tawa semasa perkuliahan, sahabat-sahabat seperjuanganku.

e. Untuk orang hebat Miftakhul Arifin terima kasih banyak untuk waktu dan nasihat-nasihat nya selama mengenal saya.

f. Semua pihak yang tidak dapat disebutkan satu persatu yang membantu dalam penyelesaikan karya ilmiah ini. 


\section{DAFTAR PUSTAKA}

Abdul Hafid (2017) Diskriminasi Bangsa Belanda Dalam Novel Salah Asuhan Karya Abdoel Moeis (Kajian Postkolonial). Kembara, Vol. 3, No. 2 (2017).

Denny, J.A. 2014. Menjadi Indonesia tanpa Diskriminasi (Data, Teori, dan Solisi). Jakarta: Inspirasi.co.

Escarpit, R. 2008. Sosiologi Sastra. Jakarta: Yayasan Obor Indonesia.

Fheti Wulandari Lubis (2018) Analisis Diskriminasi Pada Novel "Amelia" Karya Tere-Liye. Journal of Science and Social Research, ISSN 2615 - 4307 (Print), February 2018, I (1):53-59, ISSN 2615-3262 (Online).

Fulthoni, et, al. 2009. Buku Saku Kebebasan Beragama. Jakarta: The Indonesian Legal Resource Center (IRLC).

Liliweri, Alo. 2005. Prasangka \& Konflik Komunikasi Lintas Budaya Masyarakat Multikultural. Yogyakarta: LKiS.

Linda Unsriana (2014) Diskriminasi Gender Dalam Novel Ginko Karya Junichi Watanabe. Jurnal LINGUA CULTURA, Vol. 8, No. 1, May 2014.

Mahayana, Maman S. 2007. Ekstrinsikalitas Sastra Indonesia. Jakarta: Raja Grafindo Persada.

Nurgiyantoro, B. 2010. Penilaian Pembelajaran Bahasa. Yogyakarta: BPFE.

Ratna, Nyoman Kuta. 2003. Paradigma Sosiologi Sastra. Yogyakarta: Pustaka Pelajar.

Reslawati. 2007. Komunika Majalah Ilmiah Komunikasi dalam Pembangunan. Palembang: LIPI.
Rusdian Noor D. dan Joko Santoso (2017) Pemakaian Majas dalam Novel Anak Semua Bangsa Karya Pramoedya Ananta Toer: Studi Stilistika. CARAKA, Vol. 3, No. 2, Edisi Juni 2017.

Saryono. 2009. Pengantar Apresiasi Sastra. Malang: Universitas Negeri Malang.

Santika, I. G. N., Rindawan, I. K., \& Sujana, I. G. (2019). Memperkuat Pancasila Melalui Pergub No. 79 Tahun 2018 Dalam Menanggulangi Pengikisan Budaya Di Era Revolusi Industri 4.0. Prosiding Seminar Nasional Inobali 2019, 79, 981-990

Santika, I. G. N., Sujana, G., \& Winaya., M. A. (2019). Membangun Kesadaran Integratif Bangsa Indonesia Melalui Refleksi Perjalanan Historis Pancasila Dalam Perspektif Konflik Ideologis. Jurnal Etika Demokrasi (JED). 4 (2), 8998.

https://doi.org/10.26618/jed.v4i2.2 $\underline{391}$

Sayuti, A. Suminto. 1996. Apresiasi Prosa Fiksi. Jakarta: Departemen Pendidikan dan Kebudayaan.

Sudjiman, Panuti. 1991. Memahami Cerita Rekaan. Jakarta: Pustaka Jaya.

Sugihastuti. 2007. Teori Apresiasi Sastra. Yogyakarta: Pustaka Pelajar.

Sunarto, Kamanto. 2004. Pengantar Sosiologi. Jakarta: Lembaga Penerbit Fakultas Ekonomi, Universitas Indonesia.

Sri Wahyuningtyas \& Wijaya Heru Santoso. 2011. Sastra: Teori dan Implementasi. Surakarta: Yuma Pustaka. 
Wellek, Rene dan Warren Austin. 2014.

Teori Kesusastraan. Jakarta:

Gramedia.

Yudiono, K. S. 2009. Pengkajian kritik sastra Indonesia. Jakarta: Gramedia. 